Copyright (C) 2021 by Cherkas Global University

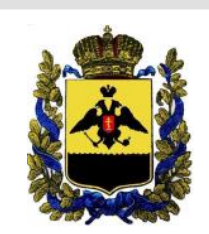

Published in the USA

Bylye Gody

Has been issued since 2006.

E-ISSN: $2310-0028$

2021. 16(4): 1728-1736

DOI: $10.13187 /$ bg.2021.4.1728

Journal homepage:

https://bg.cherkasgu.press

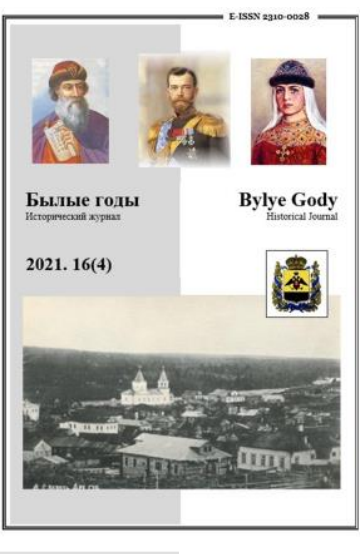

\title{
Economic and Political Development of the Grand Duchy of Finland (1809-1917)
}

Ivan S. Denisov a , b , *

a Plekhanov Russian University of Economics, Moscow, Russian Federation

b Financial University under the Government of the Russian Federation, Moscow, Russian Federation

\section{Abstract}

This article is devoted to the economic and political development of the Grand Duchy of Finland from 1809 to 1917 . The authors consider the political and economic situation of the region throughout the entire period of the existence of the Grand Duchy of Finland as part of the Russian Empire, as well as the prerequisites for Finland's accession to the empire. The article describes the political structure, as well as the procedure for the formation and implementation of governance in the Grand Duchy. The powers of the legislative, executive and judicial authorities, including and the forms of their actual performance of their functions, are also examined in detail. The article formulates the main four stages of the economic policy of the Grand Duchy of Finland: the first stage - from 1809 to the 1830 s, the second stage - from the 1830 s to the end of the 1850 s, the third stage - from the late 1850 s to the mid-1880s and the fourth stage - from the mid-1880s to the end of the First World War. The study includes a detailed analysis of each of these stages, as well as consideration of key reforms and historical events that have had a significant impact on the economic and political development of the region. Special attention is paid to the reforms of Alexander II, known as the reformer emperor, who made a significant contribution to the successful development of the region. Conclusions are formulated regarding the high importance of the so-called "Russian period" in the history of Finland. The empirical study of the article was conducted in accordance with the method of comparative historical research based on secondary sources, including pre-revolutionary literature.

Keywords: the Russian Empire, the Grand Duchy of Finland, reforms, economic development, political development.

\section{1. Введение}

История Великого княжества Финляндского как генерал-губернаторства Российской империи берет свое начало в 1809 году (эпоха императора Александра I). До присоединения к России Финляндия на протяжении шестисот лет входила в состав Швеции, однако по итогам последней русско-шведской войны (Финляндской войны) 1808-1809 гг. шведская провинция Суоми перешла под власть Российской империи. Как отмечает ряд авторов, «до присоединения к России у финнов не было своей государственности, территория Финляндии являлась провинцией Швеции и жила по шведским законам» (Гинзбург, Хащина, 2019: 130).

Предысторией русско-шведской войны является завоевательная политика Наполеона I Бонапарта. Согласно Тильзитскому договору (1807г.) Россия должна была оказать давление на Швецию в целях введения эмбарго против Англии.

Война началась в феврале 1808 года и с самого начала была невыгодной для Швеции. Основная тактика финских войск заключалась в том, чтобы замедлить продвижение России и дождаться вспомогательных войск из Швеции. Несмотря на победу на реке Сийкайоки, морские форты финского региона (Свартхольма, Виапори) сдались почти без боев. Договор о прекращении огня был

${ }^{*}$ Corresponding author

E-mail addresses: is.denisov@mail.ru (I.S. Denisov) 
подписан в ноябре 1808 в Олькийоки (Финляндия). Согласно Фридрихсгамскому мирному договору от 05 (17) сентября 1809 года, территория Финляндии вошла в состав России.

Присоединение Финляндии к Российской империи является одним из ключевых моментов развития этого края. Тема экономического и политического развития Великого княжества Финляндского представляет немалый научный интерес. Одна из основных целей данного исследования - проследить путь Финляндии от шведской провинции к независимому государству в период нахождения в составе Российской империи.

\section{2. Материалы и методы}

В качестве источниковой базы исследования был привлечен комплекс источников, включающий в себя: нормативные правовые акты, регламентирующие общественные отношения края, архивные материалы, в частности Основного русского фонда НСБ РГИА (Санкт-Петербург, Российская Федерация), а именно Сборник постановлений Великого княжества Финляндского узаконений и правительственных распоряжений 1913 года, а также материалы периодической печати - журнал «Мирской вестник».

В разработке исследования использован принцип историзма, при помощи которого была проведена комплексная оценка источников и историографии по заданной теме, а также сформулирована периодизация политического и экономического развития Великого княжества Финляндского. Также были использованы сравнительно-правовой метод, который дал возможность исследовать механизмы осуществления административного управления регионом, и структурный метод, позволивший выявить ключевые мотивы и обстоятельства развития Великого княжества Финляндского.

\section{3. Обсуждение}

Историографии Великого княжества Финляндского посвящено немало работ. Среди дореволюционных авторов в первую очередь необходимо отметить фундаментальное исследование историка и военного юриста, родившегося в Финляндии, М.М. Бородкина: «История Финляндии. Время императора Александра II». По мнению М.М. Бородкина, период правления Александра II составляет важнейшую эпоху в истории Финляндии (Бородкин, 1908: 2).

В исследованиях советских ученых по данной теме наибольшее значение придается влиянию экономических факторов на политическое развитие края. А некоторые авторы, в частности П.А.Зайончковский, стремились отразить как влияние экономического развития страны на государственный аппарат, так и обратный процесс - как государственный аппарат отражал интересы экономического развития России (Зайончковский, 1970: 5).

Современные ученые благодаря большему объему источников, введенных в научный оборот, стараются более детально рассмотреть и проанализировать ключевые предпосылки для изменения направления политики Российской империи в отношении Великого княжества Финляндского, а также влияние русского периода на последующее развитие Финляндии как независимого государства. По мнению современных исследователей, положение Финляндии в составе империи на протяжении более чем ста лет претерпело существенные изменения (Новикова, 1997: 130). Как отмечает С.Н. Погодин, «лишь после вхождения в состав русского государства началось формирование финской политической нации, политическое воспитание финского народа и его национального сознания» (Погодин, 2015b: 348).

Доктор философии, доцент Хельсинкского университета Марина Витухновская-Кауппала уделяет отдельное внимание периоду правления Александра II: «Инициированные императором либеральные экономические реформы, призванные прежде всего компенсировать ущерб, нанесенный прошедшей войной, стали толчком к ускоренной модернизации края» (ВитухновскаяКауппала, 2012: 262). А.В. Звонарев справедливо отмечает также важность решения Александра II о созыве финского парламента после длительного перерыва: «Созыв в 1863 году Сейма, не собиравшегося с 1809 года, завершил так называемый «бессеймовый период» в истории Великого княжества Финляндского и положил начало целому ряду либеральных реформ, проведенных в княжестве в правление Александра II» (Звонарев, 2016: 67).

По мнению Т.В. Андреевой, одну из ключевых ролей в развитии Великого княжества Финляндского сыграл так называемый «Николаевский период»: «Николаевское царствование занимает особое место в «русском периоде» истории Финляндии: оно стало «мостом» между «дней Александровых прекрасным началом» и утверждением либерального курса в эпоху Александра II, проявив и сфокусировав многочисленные проблемы и противоречия, вытекавшие из уникального юридического, политического и экономического статуса княжества» (Андреева, 2015: 52).

В целом нельзя не согласиться с А.В. Филоновым, который называет взаимодействие Великого княжества Финляндского с Российской империей «...достаточно сложным и многоаспективным процессом, научное осмысление которого остается актуальным до настоящего времени» (Филонов, 2019: 60). 


\section{4. Результаты}

Важнейшим структурным фактором, определявшим политику в тот период, было вхождение Финляндии в состав Российской империи. Фридрихсгамский договор положил конец войне $1808-$ 1809 годов. В ходе боевых действий Россия оккупировала большие территории Финляндии и нанесла поражение шведам. По мирному соглашению оккупированные территории (Финляндия и Аландские острова) перешли под контроль Российской империи. В результате подписания документа было образовано Великое княжество Финляндское, вошедшее в состав Российской империи.

В составе Российской империи Великое княжество Финляндское образовало автономию со своими законами и администрацией. Политика Финляндии стала частью национальной политики России. Формально Финляндия была независимой политической единицей как Великое княжество во главе с российским императором, решения которого принимались отдельно от принятия решений на национальном уровне, хотя на практике финская политика согласовывалась с национальной политикой Российской империи (Мирской вестник, 1872: 4).

Решение всех дел Великого княжества Финляндского передавалось непосредственно императору, минуя административный аппарат Российской империи, то есть российский парламент никак не мог вмешиваться в дела Финляндии.

Основным законом княжества был «Высочайший Его Императорского Величества Сеймовый Устав для Великого княжества Финляндского» (фин. Keisarillisen Majesteetin Armollinen Valtiopäiväjärjestys Suomen Suuriruhtinanmaalle, Hans kejserliga majestäts nåd.landtdagsordning för storfurstendömet Finland). Функции органа исполнительной власти выполнял Сенат, в состав которого входили экономический департамент и департамент юстиции. Экономический департамент включал в себя в том числе канцелярию, финансовый, военный и церковный комитеты, а департамент юстиции представлял судебную власть в качестве Верховного суда Финляндии. Сенатом в качестве председателя руководил генерал-губернатор Великого княжества, назначаемый императором на определенный срок исполнения полномочий. Сенаторы, являющиеся членами Сената, были гражданами Финляндии. Деятельность экономического департамента и департамента юстиции контролировали вицепредседатели Сената. Система органов местного самоуправления не была столь развита вплоть до конца XIX века, когда были созданы основы городского и муниципального управления.

Сенат долгое время исполнял на практике в том числе и функции органа законодательной власти, хотя был наделен только полномочиями законотворчества. Предполагалась, что законопроекты, предложенные Сенатом, после одобрения императором должны были приниматься или отклоняться после обсуждения финским сеймом (парламентом). В то же время стоит заметить, что ни при Александре I, ни при Николае I парламент не созывался ни разу. Поэтому в тот период законопроекты Сената становились законами сразу же после одобрения императором. Таким образом, в отсутствие парламента администрация, возглавляемая дворянством, управляла регионом единолично, что не предполагало собой становление политической конкуренции. Однако с приходом к власти императора Александра II в 1855 году ситуация изменилась. Император поручил созывать сейм, в результате чего первое собрание финского парламента после столь длительного перерыва произошло в 1863 году. В дальнейшем сейм стал созываться на регулярной основе, что послужило становлению политической конкуренции путем формирования политических партий Великого княжества Финляндского. В то же время необходимо отметить, что власть императора оставалась неограниченной. Великий князь Финляндский был вправе не подтвердить решения, принятые парламентом или вовсе распустить его.

В 1809 году указом Александра I была образована Комиссия финляндских дел (фин. Suomen asian komissiolla), которая два года спустя была преобразована в Комитет по делам Финляндии (фин. Suomen asiain komitea). Данный Комитет представлял из себя административный орган власти, расположенный в Санкт-Петербурге. В его задачи входила подготовка дел Великого княжества для передачи их императору. Функционировал данный орган под председательством государственного секретаря Российской империи. Как отмечает финский историк и политолог О. Юссила, «это произошедшее в 1811 г. изменение имело болышое значение для повышения статуса Финляндии до положения, близкого к положению Польши после 1815 г. Помимо Финляндии только Польша имела в Российской империи своего отдельного статс-секретаря для доклада дел императору» (Юссила, 2009: 115).

В период автономии Финляндия имела собственное таможенное управление. Однако у Великого княжества не было собственной внешней политики и вооруженных сил. Православная церковь и некоторые школы действовали под управлением Российской империи.

В целом можно заключить, что Великое княжество было автономным государством со своим законодательством и администрацией. У страны был также свой бюджет и таможенная граница с империей.

В 1810 году население России превысило 40 млн, в то время как население Финляндии составляло менее 900 тыс. (Хьерппе, Хьерппе, 2017: 11). Жители Финляндии делились на различные сословия, что определяло социальный статус и особые права. В XIX веке большинство жителей Финляндии проживало в сельской местности. Однако уже к 1820-1830 гг. был ярко выражен рост числа государственных служащих в центральных учреждениях и уездных администрациях. Между 1860 и

$$
-1730-
$$


1890 годами общее число чиновников центрального правительства увеличилось с 4700 до 11100 человек. К 1880 году центральная администрация Великого княжества Финляндского стала больше, чем провинциальная администрация, унаследованная от шведского периода. К 1914 году количество чиновников выросло до 27 тыс. человек. Если первоначально состав государственных служащих в большей степени состоял из дворян, в особенности в отношении наиболее высоких политически важных должностей, то к концу периода автономии доля дворянства существенно снизилась.

Анализируя экономическую политику Великого княжества Финляндского, можно в целом выделить четыре основных этапа: первый - с 1809 по 1830-е годы; второй - с 1830-х до конца 1850-х годов; третий - с конца 1850-х до середины 1880-х годов; четвертый - с середины 1880-х до конца Первой мировой войны.

Наиболее значимым для будущей экономической политики и экономического развития Великого княжества Финляндского по праву считается первый этап, который начинается с момента вхождения Финляндии в состав Российской империи в 1809 году. Его Значимость обусловлена в первую очередь присоединением к Российской империи, что стало началом для новой таможенной, транспортной, денежно-кредитной, а также фискальной политики Великого княжества. Не менее значимым элементом является формирование собственного административного аппарата.

Спустя три года после образования Великого княжества Финляндского, а именно 12 апреля 1812 года, его столица по решению Александра I была перенесена из города Турку, расположенного на юго-западе Финляндии, в Хельсинки.

В 1812 году Хельсинки представлял из себя маленькую финскую деревню с довольно скромной численностью населения (около 4 тыс. человек) по сравнению с крупным административным и торговым центром Турку. Первостепенным мотивом решения о переносе столицы являлось близкое расположение бывшей столицы к Швеции, причем как географически, так и ментально. В качестве основных преимуществ Хельсинки можно назвать близость к Санкт-Петербургу (300 км), а также наличие важной в военном отношении морской крепости Виапори. В дальнейшем Хельсинки стремительно рос и уже к концу XIX века превратился в современный европейский город.

Еще одно значение первого периода - создание собственной администрации Финляндии. Важнейшей его особенностью было то, что в сформированном административном аппарате большую часть занимали финские чиновники. Этот период также ознаменовал для Финляндии начало самостоятельного управления экономической политикой. Страна получила собственный независимый бюджет, расходы которого можно было использовать исключительно на благо Великого княжества и который покрывался доходами страны, важнейшими из которых были таможенные пошлины.

Безусловно, такие крупные политические изменения, как вхождение Финляндии в состав Российской империи, не могли не вызвать волну переживаний и волнений у финнов. Для некоторых слоев населения перспектива быть отрезанными от шведского рынка представлялась как политической, так и экономической катастрофой. Важным соглашением для подавления подобных настроений и для долгосрочного экономического развития Финляндии стал Фридрихсгамский мирный договор, который поддерживал торговые соглашения между Финляндией и Швецией. Как отмечает Тетерина E.Е., император Александр I в целях обеспечения безопасности северных границ принял решение об определении особых льготных правил регулирования торговли со Швецией, которые заключались в беспрепятственном товарообмене между Великим княжеством Финляндским и Швецией (Тетерина, 1995: 110).

Таким образом, торговля между Финляндией и Швецией была практически беспошлинной. Для предотвращения беспошлинного ввоза иностранных товаров из Швеции через Финляндию в Россию потребовалось установить отдельную таможенную границу между Финляндией и Россией. Это означало, что у Финляндии появилась собственная таможенная территория. В тот период наибольшую часть доходов Великого княжества составляли таможенные сборы.

Финляндия экспортировала сельскохозяйственную продукцию в Швецию, а финским металлургическим заводам, которые испытывали нехватку внутреннего сырья, разрешили продолжить импорт железной руды и кованого железа из Швеции. Большая часть товаров, импортируемых из Швеции, была освобождена от ввозных таможенных пошлин. В 1822 году Великое княжество ввело превентивный импортный тариф в соответствии с российским тарифом, который действовал до 1850-х годов. В 1821 г. были введены таможенные пошлины на зерно, которые действовали до конца 1850-х гг.

Рассматривая внутреннею и внешнюю политику того периода в целом, можно согласиться с учеными М.С. Белоусовым и Я.С. Абдуллаевым в том, что основной политической целью императора Александра I было «укрепление стратегического положения во всех регионах страны» (Белоусов, Абдуллаев, 2020: 554).

Второй этап экономической политики Великого княжества Финляндского, начавшийся в 30-х годах XIX века, характеризуется большим отдалением от Швеции и более глубокой интеграцией в Российскую империю. 1844 год ознаменован концом беспошлинного экспорта из Финляндии в Швецию и беспошлинного импорта Швецией сельскохозяйственной продукции. Потеря шведского

$$
-1731-
$$


рынка была компенсирована освобождением животноводства и продуктов животноводства от экспортных сборов в 1834 г. и уплатой экспортных надбавок за масло и другие продукты животноводства при условии, что они экспортировались не в Швецию. Были приняты меры по расширению посевов и развитию внутренней торговли зерном.

В целях снижения влияния Швеции был принят такой документ, как «Положение о торговых сношениях империи с Великим Княжеством Финляндским» 1835 года (РГИА. Ф. 1276. Оп. 18. Д. 486. Л. 16; Сборник постановлений..., 1913). Таким образом, таможенные пошлины стали основным источником доходов бюджета Великого княжества на протяжении всего периода автономии. Положение 1835 года положило начало финско-российским торговым отношениям на более чем два десятилетия и значительно расширило беспошлинный экспорт Финляндии в Россию, в результате чего к началу 1840-х годов доля Швеции в финском экспорте упала до одной десятой, а импорт сократился до одной шестой. Россия стала важнейшим торговым партнером Финляндии: в начале 1840-х годов ее доля превысила долю Швеции в импорте в два раза, а в экспорте в два с половиной раза.

Еще одой задачей того периода был вывод шведских денег из оборота в Великом княжестве Финляндском. Несмотря на то, что российский серебряный рубль официально был основной валютой Финляндии, шведские деньги были самой распространенной валютой до конца 1830-х годов. В 1840 году, в период проведения Денежной реформы в России 1839-1843 годов, была запущена программа реализации денег в Великом княжестве Финляндском, которая заменила старые банкнотные рубли депозитными банкнотами Банка Финляндии и серебряными рублями. Банк Финляндии получил право выпускать банкноты и производить обмен российских банкнот, а также выкуп из обращения шведских банкнот (Анисимова, 2019: 158). В то же время была проведена девальвация, которая снизила стоимость денег почти на две трети. Реализация денег означала создание собственной финской денежной системы и собственного центрального банка, хотя основной государственной валютой оставался российский рубль.

Политика правления императора Николая I характеризуется ужесточением цензуры Российской империи в отношении Великого княжества Финляндского. В качестве самого жесткого проявления цензуры многие авторы называют Высочайший рескрипт, принятый в 1850 году (РГИА. Ф. 1276. Оп. 18. Д. 486. Л. 16; Сборник постановлений..., 1913), который налагал запрет на публикацию любой литературы на финском языке, за исключением книг религиозного и экономического содержания. По мнению Д.Е. Колесникова, цензурные запреты стали основной отправной точкой финского национализма (Колесников, 2009: 66).

Третий этап экономической политики связан в первую очередь с реформами императорареформатора Александра II. Как справедливо отмечает С.Н. Погодин, «вступление Александра II на престол определило во многом проведение преобразований, затронувших все стороны жизни населения, от отмены крепостного права, до военной, судебной и университетской и школьной реформ» (Погодин, 2015а: 314).

Император, благодаря проведению масштабных либеральных реформ, заслужил весомый авторитет у финского народа. С 1894 года и по сегодняшний день именно его бронзовая статуя украшает Сенатскую площадь в Хельсинки. Третий этап экономической политики Великого княжества Финляндского берет свое начало в 1856 году, так как в марте этого года император лично председательствовал на заседании финляндского Сената, где были определены основные реформы в Великом княжестве (Бородкин 1908: 25). На данном заседании был представлен всеобъемлющий план развития финской промышленности. Было предложено около 6о мер, часть из которых была направлена на переход от меркантилизма к системе экономического либерализма, а другая часть на независимое от империи экономическое развитие.

Железная дорога Хельсинки-Хямеэнлинна, открытая в 1862 году, положила начало строительству железнодорожной сети. В 1870 году железная дорога соединила Великое княжество с Санкт-Петербургом. В 1856 году было открыто судоходное движение по Сайменскому каналу между озером Сайма в Финляндии и Выборгским заливом в России. Как отмечает историк П.О. Морозов, открытие данного канала оказало существенное положительное влияние на развитие путей сообщения, результатом чего стало усиленное развитие лесной промышленности и торговли лесом (Морозов, 1895: 14).

Финляндия получила право взимать импортные пошлины с российской продукции. Таким образом, беспошлинный импорт российских иностранных товаров снизился. Увеличилось количество товаров, беспошлинно экспортируемых в Россию. Пошлины на зерновые были отменены в 1864 году.

Частный коммерческий банкинг начался с учреждения в 1862 году Финляндского объединенного банка (фин. Suomen Yhdyspankki). Позднее, в 1873 году, начал свою деятельность Банк северных стран. Всего же в период с 1862 по 1913 годы было создано 15 коммерческих банков, 12 из которых продолжали осуществлять свою деятельность в 1913 году.

В конце 1850-х годов была начата реформа технического образования. Хельсинкская техническая реальная школа (фин. (Helsingin Teknillinen reaalikoulu) к 1872 году была преобразована в политехническую школу (фин. Polyteknillinen koulu), затем в 1879 году - в политехническое училище (фин. Polyteknillinen Opisto), а в 1908 году - в Финскую высшую техническую школу 
(фин. Suomen Teknillinen Korkeakoulu). Данное образовательное учреждение действует до сих пор и на сегодняшний день именуется как Технологический институт университета Аалто (фин. Aaltoyliopiston teknillinen korkeakoulu). Указом 1885 года были также учреждены промышленные школы в городах Хельсинки, Турку, Вааса, Куопио, Тампере и Виипури (Выборг).

Влияние Швеции на финское общество было по-прежнему существенным, в том числе по причине преобладания шведского языка. Постепенно произошел некий политический раскол, разделивший общество на свекоманов (поддерживающих шведский язык) и фенноманов (сторонников движения, направленного на переход со шведского языка на финский). Идеи данных политических движений были во многом полярны, за исключением одного - стремления обретения независимости по отношению к Российской империи. Вопрос о государственном языке стал особенно острым, начиная с 1880-х годов. Император Александр II, осознавая опасность влияния Швеции, принял решение поддержать фенноманов, таким образом финский язык стал государственным.

Четвертый этап экономической политики Великого княжества Финляндского связан с эпохой правления Александра III, а также его сына - Николая II. По мнению авторов, в качестве более точного указания года начала четвертого периода справедливо считать 1885 год. В этом году был издан указ, повышающий таможенные тарифы на ввоз товаров из Финляндии в Россию (Титов, 2021: 140), таким образом привилегии финских продуктов на российском рынке были существенное сужены.

Данный этап экономической политики характеризуется ростом русского национализма, в рамках которого были реализованы действия по снижению особого положения Финляндии, на что Финляндия отреагировала мерами, находящимися в ее распоряжении. Как отмечает А.В. Сосновских, Александр III и его сын Николай II изменили национальную политику всего государства, придав первостепенно важное значение так называемому «русскому» интересу (Сосновских, 2016: 126).

В 1890 году деятельность финской почтовой, денежной и таможенных систем были гармонизированы и интегрированы в систему Российской империи. В качестве еще одного фактора усиления интеграции Финляндии можно назвать активное строительство железнодорожной сети в Восточной Финляндии с целью улучшения дорожного сообщения с империей, в то время как участок, соединяющий Финляндию и Швецию, считался политически нежелательным.

Одним из ключевых событий, оказавших значительное влияние на экономическую ситуацию в стране в конце XIX века, можно назвать аграрный кризис, который нанес существенный удар по сельскому хозяйству (речь идет в первую очередь о зерне). Основным проявлением аграрного кризиса является существенное падение цен на зерно и ужесточение конкуренции между странамиэкспортерами. В результате рентабельность отечественного производства зерна существенно снизилась. В 1890-е годы Россия уступила Германской империи свои позиции на рынке зерна в Великом княжестве Финляндском. В итоге это привело к тому, что Российская империя стала требовать уплаты таможенных пошлин. Конец беспошлинной торговли ослабил условия работы российских экспортных отраслей, что привело к увеличению импортных пошлин в 1886 и 1888 годах. Были введены импортные пошлины на сельскохозяйственную технику, оборудование для молочного производства, а также на прочую технику. Причем тарифы регулярно повышались, и в целом пошлины были увеличены как минимум в три раза. Таким образом, повышение тарифов Россией в 1886, 1887 и 1890 годах и попытки устранить особый статус Великого княжества Финляндского в таможенной политике привели к очередному увеличению таможенных пошлин в 1897 году. Великое княжество отреагировало на данное положение дел увеличением экспорта в страны западной Европы.

В отношении промышленного производства можно говорить о его существенном развитии на данном этапе. Если в 60-х-80-х годах XIX века промышленное производство представляли мелкие и средние предприятия, то в конце XIX - начале XX веков стало появляться все больше крупных заводов и фабрик. Также росли и количественные показатели, выраженные в росте численности самих предприятий, рабочих и общем суммарном производстве. (Бобович, 1968: 50).

В качестве еще одной из ключевых реформ, принятых в Великом княжестве Финляндском, можно назвать так называемую Парламентскую реформу 1906 года, основанную на всеобщем и равном избирательном праве, в результате которой возрастной ценз для избирательных прав составил 24 года, причем право голоса получили в том числе и женщины. Таким образом, число людей, имеющих право голоса, увеличилось в десять раз - со 126000 до 1273000 человек, причем женщины Финляндии первыми в Европе получили право не только голосовать, но и быть избранными. В итоге в 1907 году на первых парламентских выборах после данной реформы было избрано 19 женщин-депутатов.

Политику, проводимую Российской империей по отношению к Великому княжеству Финляндскому в конце XIX - начале XX веков, в целом можно охарактеризовать таким понятием, как «русификация Финляндии». В 1914 году была даже обнародована программа, известная как «широкая программа русификации». Однако она так и не была воплощена в жизнь по причине первой мировой войны и революции в России (Юссила, 2010: 114). В результате революции 1917 года Финляндия обрела независимость. 


\section{5. Заключение}

В заключение статьи можно констатировать, что наиболее важным структурным фактором, определяющим политику Великого княжества Финляндского, было его положение в Российской империи. Великое княжество было автономным государством со своим законодательством, парламентом, администрацией, бюджетом и таможенной территорией. Однако политика Финляндии была частью национальной политики России.

Экономическая политика Великого княжества Финляндского разделена на четыре периода. Первостепенное значение представляет первый этап, длившийся с 1809 года по 1830-е годы, когда Финляндия стала частью Российской империи, а также была создана собственная администрация Финляндии. Важным механизмом для экономического развития стал Фридрихсгамский мирный договор от 5 (17) сентября 1809 года, в результате которого Финляндия получила свою собственную таможенную зону.

Значение второго этапа, который продлился с 1830-х до конца 1850-х годов, заключается в первую очередь в преодолении Финляндией экономической зависимости от Швеции и более тесной интеграции региона в Российскую империю. Третий период был начат программой реформ, продиктованной императором Александром II в 1856 году, которая осуществила переход страны от меркантилизма к системе экономического либерализма. Четвертый период начался в 1885 году, когда Россия начала политику, направленную на подрыв достигнутой политической и экономической автономии. В то же время европейский аграрный кризис вызвал реструктуризацию сельского хозяйства. Концом четвертого периода является 1917 год, когда Финляндия обрела независимость.

\section{Литература}

Андреева, 2015 - Андреева Т.В. Николай I и финляндский вопрос. 1830-1831 гг. // Петербургский исторический журнал. 2015. № 2 (о6). С. 52-78.

Анисимова, 2019 - Анисимова Д.В. Монетарные реформы Великого княжества Финляндского в контексте интеграционной политики Российской империи // Исторический журнал: научные исследования. 2019. № 3. С. 157-166.

Бобович, 1968 - Бобович И.М. Русско-финляндские экономические отношения накануне Великой Октябрьской социалистической революции. Л., 1968. 191 с.

Бородкин, 1908 - Бородкин М.M. История Финляндии. Время императора Александра II / М. Бородкин. СПб.: Гос. тип., 1908. XVIII, 571 с.

Витухновская-Кауппала, 2012 - Витухновская-Кауппала M. «Он снова с нами!» Александр II в исторической памяти финнов в начале XX в. / Коллектив авторов // Александр II. Трагедия реформатора: люди в судьбах реформ, реформы в судьбах людей: Сборник статей. СПб.: Изд-во Европ. ун-та в Санкт-Петербурге, 2012. С. 262-281.

Гинзбург, Хащина, 2019 - Гинзбург Ю.В., Хащина Э.Э. Выход Польши и Финляндии из состава России: историко-правовые аспекты // Историко-правовые проблемы: Новый ракурс. 2019. № 2. C. $123-136$.

Зайончковский, 1970 - Зайончковский П.А. Российское самодержавие в конце XIX столетия. М., 1970. $444 \mathrm{c}$

Звонарев, 2016 - Звонарев А.В. Правовое положение финляндского сейма по сеймовому уставу Великого княжества Финляндского 1869 года // Российское государствоведение. 2016. № 3. С. 66-73.

Колесников, 2009 - Колесников Д.Е. Финское национальное пробуждение как политический феномен (в период правления Николая I) // Известия высших учебных заведений. СевероКавказский регион. Общественные науки. 2009. № 5. С. 64-68.

Морозов, 1895 - Морозов П.О. Финляндия в торгово-промышленном отношении / Министерство финансов. Деп. торговли и мануфактур. СПб.: Тип. Б. Брауде. 1895. 91 с.

Мирской вестник, 1872 - Мирской вестник. № 61. 1872.

Новикова, 1997 - Новикова И.Н. Великое княжество Финляндское в имперской политике России // Имперский строй России в региональном измерении (ХIX - начало XX века): Сборник статей / Отв. ред. Савельев П.И. Московский общественный научный фонд. 1997. С. 130-149.

Погодин, 2015а - Погодин С.Н. Реформы Александра II в Великом княжестве Финляндском // Россия в глобальном мире. 2015. № 7 (30). С. 314-324.

Погодин, 2015b - Погодин С.Н. Фенномания и процесс становления национального самосознания в Российской империи в XIX веке // Международные отношения и диалог культур. 2015. № 3 (2014). С. 347-356.

РГИА - Российский государственный исторический архив.

Сборник постановлений..., 1913 - Сборник постановлений Великого княжества Финляндского узаконений и правительственных распоряжений. 1913.

Сосновских, 2016 - Сосновских А.В. Национальная политика Российской империи в отношении Финляндии в период конца XIX - начала XX века и ее влияние на развитие кризисной ситуации в государстве // Социально-экономические науки и гуманитарные исследования. 2016. № 11. С. 125-129. 
Тетерина, 1995 - Тетерина E.E. Таможенное законодательство Великого княжества Финляндского в первой половине XIX века // Известия высших учебных заведений. Правоведение. 1995. № 1. С. 108-114.

Филонов, 2019 - Филонов А.В. Особенности правового статуса Великого княжества Финляндского в составе Российской империи // Образование. Наука. Научные кадры. 2019. № 4. С. 60-64.

Хьерппе, Хьерппе, 2017 - Хъерппе P.T., Хъерппе Р.T. Экономика великого княжества финляндского и русская революция 1917 г. // Экономическая история. 2017. Т. 13. № 4. С. 9-18.

Юссила, 2009 - Юссила О. Великое княжество Финляндское, 1809-1917. Хельсинки, 2009. 860 с.

Юссила и др., 2010 - Юссила О., Хентиля С., Невакиви Ю. Политическая история Финляндии, 1809-2009. M., 2010. $471 \mathrm{c.}$

Belousov, Abdullaev, 2020 - Belousov M.S., Abdullaev Y.S. The Foreign Context of the Integration Process of Finland into the Russian Empire // Bylye Gody. 2020. 56(2): 549-557.

Titov, 2021 - Titov V.V. (2021). Formation of the All-Russian Imperial Identity in the Grand Duchy of Finland during the Reign of Alexander III: Historical Contexts and Political Restrictions // Bylye Gody. 2021. 16(1): 138-145.

\section{References}

Andreeva, 2015 - Andreeva, T.V. (2015). Nikolai I i finlyandskii vopros. 1830-1831 gg. [Nicholas I and the Finnish Question. 1830-1831]. Peterburgskii istoricheskii zhurnal. 2(06): 52-78. [in Russian]

Anisimova, 2019 - Anisimova, D.V. (2019). Monetarnye reformy Velikogo knyazhestva Finlyandskogo $\mathrm{v}$ kontekste integracionnoj politiki Rossijskoj imperii [Monetary reforms of the Grand Duchy of Finland in the context of the Integration policy of the Russian Empire]. Istoricheskij zhurnal: nauchnye issledovaniya. 3: 157-166. [in Russian]

Belousov, Abdullaev, 2020 - Belousov, M.S., Abdullaev, Y.S. (2020). The Foreign Context of the Integration Process of Finland into the Russian Empire. Bylye Gody. 56 (2): 549-557.

Bobovich, 1968 - Bobovich, I.M. (1968) Russko-finlyandskie ekonomicheskie otnosheniya nakanune Velikoj Oktyabr'skoj socialisticheskoj revolyucii [Russian-Finnish economic relations on the eve of the Great October Socialist Revolution]. Lenigrad. 191 p. [in Russian]

Borodkin, 1908 - Borodkin, M.M. (1908). Istoriya Finlyandii. Vremya imperatora Aleksandra II [History of Finland. Time of Emperor Alexander II]. SPb., 571 p. [in Russian]

Filonov, 2019 - Filonov, A.V. (2019). Osobennosti pravovogo statusa Velikogo knyazhestva Finlyandskogo v sostave Rossijskoj imperii [Features of the legal status of the Grand Duchy of Finland as part of the Russian Empire]. Obrazovanie. Nauka. Nauchnye kadry. 5: 60-64. [in Russian]

Ginzburg, Hashchina, 2019 - Ginzburg, Yu.V., Hashchina, E.E. (2019). Vyhod Pol'shi i Finlyandii iz sostava Rossii: istoriko-pravovye aspekty [The withdrawal of Poland and Finland from Russia: historical and legal aspects]. Istoriko-pravovye problemy: Novyj rakurs. 2: 123-136. [in Russian]

Hjerppe, Hjerppe, 2017 - Hjerppe, R.T., Hjerppe, R.T. (2017). Ekonomika velikogo knyazhestva finlyandskogo i russkaya revolyuciya. [The economy of the grand duchy of Finland and the russian revolutions 1917]. Ekonomicheskaya istoriya. 13(4): 9-18.

Kolesnikov, 2009 - Kolesnikov, D.E. (2009). Finskoe nacional'noe probuzhdenie kak politicheskij fenomen (v period pravleniya Nikolaya I) [Finnish National Awakening as a political phenomenon (during the reign of Nicholas I)]. Izvestiya vysshih uchebnyh zavedenij. Severo-Kavkazskij region. Obshchestvennye nauki. 5: 64-68. [in Russian]

Mirskoj vestnik, 1872 - Mirskoj vestnik. 61. 1872. [in Russian]

Morozov, 1895 - Morozov, P.O. (1895). Finlyandiya v torgovo-promyshlennom otnoshenii [Finland in terms of trade and industry]. Ministerstvo finansov. Dep. torgovli i manufaktur. SPb., 91 p. [in Russian]

Novikova, 1997 - Novikova, I.N. (1997). Velikoe knyazhestvo Finlyandskoe v imperskoj politike Rossii [The Grand Duchy of Finland in the Imperial Policy of Russia]. Imperskij stroj Rossii v regional'nom izmerenii (XIX - nachalo XX veka)]: Sbornik statei. Otv. red. Savel'ev P.I. Moskovskii obshchestvennyi nauchnyi fond. Pp. 130-149. [in Russian]

Pogodin, 2015a - Pogodin, S.N. (2015). Reformy Aleksandra II v Velikom knyazhestve Finlyandskom [Reforms of Alexander II in the Grand Duchy of Finland]. Rossiya $v$ global'nom mire. 7(30): 314-324. [in Russian]

Pogodin, 2015b - Pogodin, S.N. (2015). Fennomaniya i protsess stanovleniya natsional'nogo samosoznaniya $\mathrm{v}$ Rossiiskoi Imperii $\mathrm{v}$ XIX veke [Fennomania and the process of formation of national identity in the Russian Empire in the XIX century]. Mezhdunarodnye otnosheniyai dialog kul'tur. 3: 347-356. [in Russian]

RGIA - Rossiiskii gosudarstvennyi istoricheskii arkhiv [Russian state historical archive].

Sbornik postanovlenij..., 1913 - Sbornik postanovlenij Velikogo knyazhestva Finlyandskogo uzakonenij i pravitel'stvennyh rasporyazhenij (1913). [in Russian]

Sosnovskikh, 2016 - Sosnovskikh, A.V. (2016). Natsional'naya politika Rossiiskoi imperii v otnoshenii Finlyandii v period kontsa XIX - nachala XX vekov i ee vliyanie na razvitie krizisnoi situatsii v gosudarstve 
[The national policy of the Russian Empire in relation to Finland during the late XIX - early XX centuries and its influence on the development of the crisis in the state]. Sotsial'no-ekonomicheskie nauki $i$ gumanitarnye issledovaniya. 11: 125-129. [in Russian]

Teterina, 1995 - Teterina, E.E. (1995). Tamozhennoe zakonodatel'stvo Velikogo knyazhestva Finlyandskogo v pervoj polovine XIX veka [Customs legislation of the Grand Duchy of Finland in the first half of the XIX century]. Izvestiya vysshih uchebnyh zavedenij. Pravovedenie. 1: 108-114. [in Russian]

Titov, 2021 - Titov, V.V. (2021). Formation of the All-Russian Imperial Identity in the Grand Duchy of Finland during the Reign of Alexander III: Historical Contexts and Political Restrictions. Bylye Gody. 16(1): 138-145.

Vituhnovskaya-Kauppala, 2012 - Vituhnovskaya-Kauppala, M. (2012) «On snova s nami!» Aleksandr II v istoricheskoj pamyati finnov v nachale XX v. [«He's back with us!» Alexander II in the historical memory of the Finns at the beginning of the XX century]. Group of authors. Aleksandr II. Tragediya reformatora: lyudi v sud'bah reform, reformy v sud'bah lyudej: sbornik statej. SPb., Pp. 262-281. [in Russian]

Yussila, 2009 - Yussila, O. (2009). Velikoe knyazhestvo Finlyandskoe, 1809-1917 [Grand Duchy of Finland, 1809-1917]. Helsinki, 860 p. [in Russian]

Yussila i dr., 2010 - Yussila, O., Khentilya, S., Nevakivi, Yu. (2010). Politicheskaya istoriya Finlyandii, 1809-2009 [Political history of Finland, 1809-2009]. M., 471 p. [in Russian]

Zaionchkovskii, 1970 - Zaionchkovskii, P.A. (1970). Rossiiskoe samoderzhavie v kontse XIX stoletiya [Russian autocracy at the end of the XIX century]. M., 444 p. [in Russian]

Zvonarev, 2016 - Zvonarev, A.V. (2016). Pravovoe polozhenie finlyandskogo sejma po sejmovomu ustavu Velikogo knyazhestva Finlyandskogo 1869 goda [The legal status of the Finnish Seimas according to the Seimas Charter of the Grand Duchy of Finland of 1869]. Rossijskoe gosudarstvovedenie. 3: 66-73. [in Russian]

\title{
Экономико-политическое развитие Великого княжества Финляндского (1809-1917 гг.)
}

\author{
Иван Сергеевич Денисов а, b * \\ a Российский экономический университет им. Г.В. Плеханова, Москва, Российская Федерация \\ b Финансовый университет при Правительстве Российской Федерации, Москва, \\ Российская Федерация
}

Аннотация. Данная статья посвящена экономическому и политическому развитию Великого княжества Финляндского с 1809 по 1917 гг. Автор рассматривает политическое и экономическое положение региона на протяжении всего периода существования Великого княжества Финляндского в составе Российской империи, а также предпосылки присоединения Финляндии к империи. Статья описывает политическое устройство, а также порядок формирования и осуществления управления в Великом княжестве. Также подробно рассмотрены полномочия органов законодательной, исполнительной и судебной власти, в том числе и формы их фактического исполнения своих функций. В статье определены четыре основных этапа экономической политики Великого княжества Финляндского: первый - с 1809 по 1830-е годы, второй - с 1830-х до конца 1850-х годов, третий - с конца 1850-х до середины 1880-х годов и четвертый - с середины 1880-х до конца Первой мировой войны. Исследование включает в себя подробный анализ каждого из данных этапов, а также в нем рассматриваются ключевые реформы и исторические события, оказавшие значительное влияние на экономическое и политическое развитие края. Особое внимание уделено реформам Александра II (известного как император-реформатор), внесшего значительный вклад в успешное развитие региона. Сформулированы выводы в отношении важного значения так называемого «русского периода» в истории Финляндии. Эмпирическое исследование проводилось на основе сравнительно-исторического метода с опорой на вторичные источники, в числе которых и дореволюционная литература.

Ключевые слова: Российская империя, Великое княжество Финляндское, реформы, экономическое развитие, политическое развитие.

\footnotetext{
* Корреспондирующий автор

Адреса электронной почты: is.denisov@mail.ru (И.С. Денисов) 